\title{
IMPLEMENTASI KEBIJAKAN IZIN MENDIRIKAN BANGUNAN (IMB) DALAM MENINGKATKAN PENDAPATAN ASLI DAERAH (PAD) PADA DINAS PENANAMAN MODAL PELAYANAN TERPADU SATU PINTU (DPMPTSP) KABUPATEN PANGKEP
}

\author{
Implementation of a Policy of Establishment Permit (IMB) in Increasing Regional Original Income \\ (PAD) at the One Stop Integrated Service Investment Service (DPMPTSP) Pangkep Regency
}

\author{
Syukurman ${ }^{1}$, Andi Muhibuddin ${ }^{2}$, Zainuddin Mustafa ${ }^{2}$ \\ ${ }^{1}$ Dinas Penanaman Modal dan Pelayanan Terpadu Satu Pintu Kabupaten Pangkep \\ ${ }^{2}$ Program Studi Ilmu Administrasi Negara, Program Pascasarjana, Universitas Bosowa \\ Email: syukurmanemba@gmail.com \\ Diterima: 20 September 2021 \\ Dipublikasikan: 20 Desember 2021
}

\begin{abstract}
ABSTRAK
Penelitian yang dilakukan dengan tujuan agar dapat diketahui proses dan faktor yang mempengaruhi implementasi kebijakan dan adakah pengaruh terhadap peningkatan pendapatan asli daerah (PAD) pada Dinas Penanaman Modal dan Pelayanan Terpadu Satu Pintu (DPMPTSP) Kabupaten Pangkep. Metode penelitian yang dilakukan bersifat kualitatif dengan metode deskriptif kualitatif. Yaitu memberikan pengamatan dan penggambaran terhadap aspek- aspek penelitian, kemudian meneskripsikan aspek tersebut. Untuk menentukan fakta maka peneliti melakukan wawancara, observasi beberapa informan kunci meliputi pelaksana kebijakan IMB, anggota DPRD, dan masyarakat yang bermohon. Hasil penelitian menunjukkan pada Implementasi kebijakan Izin Mendirikan Bangunan di Kabupaten Pangkep belum berjalan dengan efektif dan belum sesuai dengan keinginan pemerintah daerah. Hal ini dikarenakan belum maksimalnya penerapan kebijakan IMB ditandai dengan tidak diterapkannya waji IMB, ketentuan wajib memenuhi syarat tata bangunan. Adapun faktor yang menyebabkan tidak efektifnya implementasi kebijakan adalaah kualitas dan kwantitas staf yang masih kurang, pengawasan dan dukungan politik dari legislatif masih kurang dan komunikasi yang belum efektif yang belum berjalan dengan baik.Penerimaan retribusi IMB terhadap PAD masih sangat rendah, penerimaan retribusi selama tiga tahun terakhir tidak mengalami kenaikan sesuai target yang diharapkan pemerintah. Setiap tahunnya retribusi IMB yang diterrima Rp. 900.000 .000 dimana hanya tercapai $60 \%$ dari target yang ditentukan pemerintah Kabupaten Pangkep. Nilai kontribusi tersebut belum signifikan terhadap peningkatan PAD di Kabupaten Pangkep.
\end{abstract}

Kata Kunci: Kebijakan IMB, Pendapatan Asli Daerah, Pangkep

\begin{abstract}
The research was conducted with the aim of knowing the processes and factors that influence policy implementation and whether there is an effect on increasing local revenue (PAD) at the One Stop Integrated Service and Investment Service (DPMPTSP) Pangkep Regency. The research method carried out is qualitative with a qualitative descriptive method. That is to provide observations and descriptions of aspects of the research, then describe these aspects. To determine the facts, the researchers conducted interviews, observed several key informants including IMB policy implementers, DPRD members, and the people who applied. The results showed that the implementation of the building permit policy in Pangkep Regency had not run effectively and had not been in accordance with the wishes of the local government. This is because the implementation of the IMB policy has not been maximized, which is marked by the non-applicability of the mandatory IMB, the provisions of which must meet the building structure requirements. The factors that cause the ineffective implementation of policies are the quality and quantity of staff that are still lacking, political supervision and support from the legislature are still lacking and communication is not yet effective which has not gone well. Receipt of IMB levies on PAD is still very low, retribution receipts for three years The last one did not increase according to the target expected by the government. Each year the IMB levy received is Rp. 900,000,000 where only 60\% of the target set by the Pangkep Regency government was achieved. The value of this contribution has not been significant to the increase in PAD in Pangkep Regency.
\end{abstract}

Keywords: IMB Policy, Local Revenue, Pangkep

This work is licensed under Creative Commons Attribution License 4.0 CC-BY International license

\section{PENDAHULUAN}

Pelayanan publik adalah suatu bentuk pelayanan yang dibuat, dilakukan dan dilaksanakan pada suatu instansi untuk melakukan pelayanan publik. Hal ini dilakukan sebagai bentuk untuk membantu masyarakat untuk melaksanakan kegiatan dalam menjalankan undang-undang. Bentuk pelayanan public yang dilakukan adalah pelayanan jasa, barang maupun administrasi (Tjanggih, 2017)

Dalam meningkatkan kesejahteraan masyarakat maka instansi pemerintah membuat suatu kegiatan agar dapat mempercepat peningkatan pelayanan, 
pemberdayaan, maupun keikutsertaan dalam meningkatkan persaingan yang positif pada insansi terkaait terhadap beberapa prinsip demokrasi, pemerataan dan keadilan. Dalam suatu Negara terdiri menjadi daerah provinsi, dan daerah provinsi dibagi atas daerah kabupaten dan kota. berlakunya berdasarkan undangundang Otonomi Daerah Nomor 23 tahun 2014 tentang pemerintah daerah dengan tujuan agar mempermudah aturan dan dan pelaksanaan pemerintahan yang dapat berjalan secara mandiri dan tetap mendapatkan pengawasan pusat (Simamora, 2015)

Wewenang suatu pemerintahan Kewenangan pemerintahan dalam melakukan pembangunan yang berasal dari pemerintah pusat telah diatur berdasarkan peraturan perundang-undangan yaitu Nomor 23 tahun 2014. Pemerintah Daerah mempunyai wewenang yang besar dalam mengelola dan mengatur urusan rumah tangga sebagai prakarsa sendiri yang ddilakukan berdasarkan dengan kemampuan dan potensi dari saran masyarakat (Sumartini, 2017)

Usaha yang dilakukan untuk mendapatkan penghasilan sebagai pemasukan bagi pendapatan asli daerah (PAD) yaitu dengan melakukan pengelolaan dari beberapa sumbersumber yang dapat menghasilkan bagi daerah, hal ini menjadi aspek penentu kemampuan daerah (Sumartini, 2017)

Hasil yang didapatkan suatu daerah biasa disebut dengan pendapatan daerah, hasil ini dapat berupa pajak maupun penurunan utang dari beberapa tempat yang dikelola dalam tahun tertentu. pendapatan daerah menjadi aspek yang sangat penting dalam membangun (Putra, 2015, hal 866). Pendapatan asli daerah adalah sumbr penghasilan yang didapatkan suatu daerah yang didapatkan dari pajak (50\%), retribusi daerah $(35 \%)$, bagian laba BUMD (14\%) dan pendapatan lain-lain (1\%). Pemerintah daerah mendapatkan penghasilan berasal dari sumber daerahnya sendiri dengan megelola hasil daerah dari sumber yang potensial agar dapat membiayai daerahnya. Daerah tidak hanya mengandalkan pajak tetapi dapat mengandalkan retribusi maupun sumber (Nasir, 2015).

Banyaknya pendapatan yang didapat suatu daerah dapat dijadikan sebagai ukuran kemampuan daerah tersebut untuk menjadi mandiri dan mampu mengelola keuangan daerahnya sendiri (Mahi, 2015). Pelayanan pada masyarakat merupakan bentuk pelayanan yang diberikan pada masyarakat yaang dilaksanakan instansi pemerintah agar dapat memenuhi kebutuhan masyarakat yang telah diatur pada undang-undang. Ada beberapa pelayanan publik yang dilakukan pemerintah seperti pelayanan publik, pelayanan jasa, dan pelayanan administratif. (Mahi, 2015)

Terdapat beberapa usaha yang dilakukan untuk meningkatkan pelayanan publik oleh Sebagai upaya dalam peningkatan pelayanan publik maka pemerintah Kabupaten Pangkep menerbitkan PERDA tentang izin mendirikan bangunan yang masih memberlakukan penggunaan Peraturan Menteri Pekerjaan Umum dan Perumahan Rakyat Republik Indonesia Nomor : 05/PRT/M/2016 tentang Izin mendirikan Bangunan Gedung dan Peraturan Daerah Nomor 8 Tahun 2014 tentang retribusi IMB. Izin mendirikan bangunan merupakan bentuk perizinan yang diberikan oleh pemerintah daerah kepada pemilik bangunan untuk membangun baru, mengubah, memperluas, mengurangi, dan/atau merawat bangunan gedung sesuai dengan persyaratan administratif dan persyaratan teknis yang berlaku (DPMPTSP Kabupaten Pangkep)

Agar mendapatkan penghasilan demi meningkatkan PAD maka Kabupaten Pangkep melakukan suatu usaha dengan system yang terarah demi penghasilan daerah, salah satunya adalah retribusi Izin Mendirikan Bangunan (IMB). (DPMPTSP Kabupaten Pangkep). Hasil studi pendahuluan atau survey yang dilakukan sebelum melakukan penelitian dilakukan untuk melihat kendala yang ada dalam rangka pelaksanaan pelayanan pada DPMPTSP Kabupaten Pangkep seperti: kurangnya sumber daya manusia, profesionalisme pegawai/petugas yang belum optimal, sarana, peralatan dan fasilitas pendukung masih terbatas, dan koordinasi dengan instasi terkait lainnya belum efektif, dan kendala lainnya yang bersifat teknis dan rendahnya tingkat kesadaran masyarakat dan pemahaman tentang pentingnya memiliki IMB, keterlambatan dalam proses menindaklanjuti pengurusan IMB. (DPMPTSP Kabupaten Pangkep)

Implementasi menurut ahli yaitu Mazmanian dan Sabatier merupakan suatu bentuk pelaksanaan yang dilakukan untuk mengelola kebijakan dasar yang memiliki bentuk kebijakan yaitu Undang-Undang yang sifatnya memberikan perintah seperti keputusan badan peradilan. (Putra, 2015).

Belum efektifnya implementasi kebijakan IMB, akan berdampak terhadap kurangnya kontribusi penerimaan retribusi IMB terhadap PAD Kabupaten Pangkep selama tiga tahun terakhir. Dimana selama periode tersebut kebijakan IMB penatalaksanaannya, penerimaan retribusi yang diterima belum sesuai yang diharapkan, karena hampir setiap tahunnya tidak mencapai target yang ditentukan bahkan cenderung mengalami penurunan, terjadinya penurunan ini tidak disertai dengan pengawasan yang baik sehingga berpengaruh terhadap pemasukan bagi daerah (Ngunjunau, 2015)

Berdasarkan data penerimaan PAD kabupaten Pangkep dari DPMPTSP sejak tiga tahun terakhir mengalami penurunan, paa tahun 2018 target anggaran Rp 1.00.125.056 dan yang terealisasi hanya $(88,9 \%)$, tahun 2019 target anggaran yang sama darri tahun sebelumnya yaitu $\mathrm{Rp} 1.00 .125 .056$ dan yang terealisasi $(60,1 \%)$, dan pada tahun 2020 dari Rp 900.000.000 terealisasi hanya $(55,6 \%)$ (DPMPTSP Kabupaten Pangkep)

Dengan adanya permasalahan yang terjadi setelah dilakukan studi pendahuluan maka terdapat masalah yang membuat penulis tertarik untuk melakukan penelitian 
"Implementasi Kebijakan Izin Mendirikan Bangunan (IMB) Dalam Meningkatkan Pendapatan Asli Daerah (PAD) Pada Dinas Penanaman Modal Pelayanan Terpadu Satu Pintu Kabupaten Pangkep"METODE

Penelitian ini dilaksanakan pada bulan Februari tahun 2021. Adapun lokasi penelitian ini dilakukan di Perpustakaan Universitas Hasanuddin. Penelitian ini menggunakan pendekatan deskriptif kualitatif. Data yang digunakan dalam penelitian ini adalah data primer dan data sekunder.

Teknik pengumpulan data dilakukan dengan metode observasi, wawancara, studi kepustakaan (Library Research), dan penelusuran data online. Teknik analisis data pada penelitian ini dilakukan secara cermat dimana data diseleksi mengggunakan teknik analisis data deskriptif yaitu data-data yang telah dihimpun dan dikumpulkan baik primer maupun sekunder, kemudian diambil kesimpulan sebagai jawaban masalah yang diteliti. Pengolahan data diakukan melalui reduksi data, penyajian data dan penarikan kesimpulan dan verifikasi data. Sementara itu kredibilitas data dalam penelitian ini dilakukan melalui perpanjangan pengamatan, meningkatkan ketekunan, triangulasi data, analisis kasus negatif, menggunakan bahan referensi, dan mengadakan member check.

\section{METODE}

Metode penelitian yang digunakan adalah penelitian kualitatif dengan pendekatan deskriptif, yang proses pengumpulan datanya memungkinkan peneliti untuk menghasilkan deskripsi tentang fenomena sosial terjadi. Dilakukan pada bulan Maret 2021, data yang digunakan adalah data primer yang diambil langsung saat wawancara dan data sekunder diambil mealui laporan. Sumber data yaitu data primer dan sekunder. Untuk pengolahan data digunakan tekhnik dengan wawancara, dokumentasi, dan observasi. Analisis data dengan metode deskriptif analisis

\section{HASIL DAN PEMBAHASAN}

Pelaksanaan kebijakan reformasi birokrasi Pada Dinas Penanaman Modal dan Pelayanan Terpadu Sistem Satu Pintu Kabupaten Pangkep

Pada era otonomi daerah tidak dapat dipungkiri bahwa setiap daerah dapat membuat dan melaksanakan kebijakan strategis guna menunjang berhasilnya implementasi pembangunan didaerah. Berhasilnya implementasi kebijakan pemerintah daerah dapat memberikan kontribusi secara langsung terhadap peningkatan pendapatan daerah. Sebagai bentuk komitmen pemerintah daerah demi keberhasilan penerapan otonomi daerah. Kabupaten Pangkep memiliki Peraturan Daerah (PERDA) yang mengatur yaitu Perda Kabupaten Pangkajene dan Kepulauan dengan Nomor 8 Tahun 2011 tentang Retribusi Izin Mendirikan Bangunan (IMB).

\begin{abstract}
Kabupaten Pangkep memiliki kebijakan implementasi yang sifatnya strategis yang diimplementasikan dalam bentuk suatu kebijakan IMB yang diatur sesuai dengan Peraturan Daerah (PERDA) yang mengatur yaitu Perda Kabupaten Pangkajene dan Kepulauan Nomor 8 Tahun 2011 tentang Retribusi Izin Mendirikan Bangunan (IMB). Implementasi memiliki tujuan untuk memudahkan pengendalian bangunan fisik untuk mewujudkan pemanfaatan penataan ruang secara tertib dengan harapan dapat menambah penghasilan asli daerah yang yang didapatkan dari pungutan retribusi IMB itu sendiri. Kebijakan strategis ini telah dituangkan dalam peraturan daerah yaitu Perda No 7 Tahun 2015 yaitu Bangunan Gedung, dan Perda No 8 Tahun 2011 Tentang retribusi IMB. Penerapan kebijakan ini membawa konsekuensi pada pemohon baik pribadi, hukum maupun swasta agar terlebih dahulu memiliki izin mendirikan bangunan (IMB).
\end{abstract}

Faktor yang Menghambat Implementasi Kebijakan Pelayanan Izin Mendirikan Bangunan (IMB) yang Efektif.

Untuk menjalankan roda pemerintahan termasuk dalam pelaksanaan kebijakan pemerintah yang berhubungan dengan pelayanan publik menjadi andil yang besar bagi Pegawai Negri Sipil (PNS). PNS berperan sangat penting dalam keberhasilan ini. Disaat otonomi daerah ini pemerintah daerah wajib memiliki staf yang memiliki kompoten dibidangnya masing-masing. Kompetensi yang dimaksud seperti keterampilan, keahlian, pengetahuan dari staf Dinas Penanaman Modal dan Pelayanan Terpadu (DPMPTSP) Kabupaten Pangkep sesuai dengan tugas yang dikerjakan dalam mengimplementasikan kebijakan IMB.

Sebagai instansi tekhnis yang bertaggung jawab dalam melaksanakan kebijakan IMB di Kabupaten Pangkep, maka Dinas Penanaman Modal dan Pelayanan Terpadu (DPMPTSP) mendapatkan dukungan dari staf yang memiliki kompetensi yang baik. Dukungan staf dengan kompetensi yang memadai sangat dibutuhkan agar pekerjaan yang dilaksanakan dalam implementasi kebijakan IMB memiliki karakteristik tekhnis dan spesifik, utamanya yang berhubungan dengan penataan dan pengendalian bangunan.

Dukungan dari staf sangat berpengaruh bagi Dinas Penanaman Modal dan Pelayanan Terpadu (DPMPTSP) Kabupaten Pangkep dalam memberikan pelayanan yang berkualitas yang memuaskan masyarakat dalam mengurus IMB. Apaabila staf tidak memiliki kompetensi maka akan memperlambat dalam pelayanan.

Dalam kenyataannya Dinas Penanaman Modal dan Pelayanan Terpadu (DPMPTSP) Kabupaten pangkep mengalami banyak masalah dalam pelaksanaan kebijakan IMB yaitu masih kompetensi staf yang belum terlatih serta kurangnya tenaga ahli. Kondisi ini akan berdampak kurang efektifnya pelayanan implementasi kebijakan IMB pada masyarakat. Indikasinya karena banyaknya ditemukan pelanggaran terhadap ketentuan IMB pada masyarakat yang meelakukan pembangunan, seperti banyaknya bangunan yang tidak memiliki IMB yang 
ditemukan petugas dilapangan.Keahlian dan kemampuan seseorang bukanlah hal yang menjadi suksesnya suatu kebijakan, tidak menjamin tumbuhnya kesadaran masyarakat untuk mematuhi segala ketentuan kebijakan pemerintah daerah.

Pengawasan merupakan hal yang penting dilakukan untuk mendukung agar implementasi kebijakan IMB di Kabupaten Pangkep dapat berjalan efektif. Pengawsan sangat diperlukan agar masyarakat mejadi patuh terhadap aturan yang telah ditentukan saat mendirikan bangunan. Hal tersebut diperlukan agar pelaksanaan kebijakan daerah berjalan efektif.

Secara struktural pelaksanaan pengawasan kebijakan IMB menjadi tanggung jawab Dinas Pekerjaan Umum Kabupaten Pangkep. Secara structural perlu dilakukan pengawasan terhadap pelaksanaan implementasi kebijakan IMB juga merupakan tugas Dinas Penanaman Modal dan Pelayanan Terpadu (DPMPTSP) Kabupaten Pangkep.

Dalam menjamin efektivitas implementasi kebijakan IMB di Kabupaten Pangkep, Maka Dinas Penanaman Modal dan Pelayanan Terpadu (DPMPTSP) sebagai salah satu penanggung jawab tekhnis dan administrasi mempunyai peran dalam pengawasan dan monitoring. Dan perlu juga dilakukan koordinasi dengan pihak terkait.

Pada kenyataannya, pengawasan kebijakan IMB belum berjalan dengan efektif. Dari data yang ditemukan dilapangan masih ada masyarakat yang belum memiliki IMB dan masih banyak kendala tekhnis dilapangan seperti adanya penyimpangan aturan garis sempadan dan ketentuan jarak bebas dalam mendirikan bangunan.

Berdasarkan data tahun 2019, dari 896 bangunan hanya 486 yang memiliki IMB. Rendahnya bangunan yang memiliki IMB khusunya dari bangunan rumah tinggal, ruko, dan bangunan jasa lainnya. Yang berdampak terhadap minimnya penerimaan retribusi IMB. Dampak lain yang muncul adalah tidak teraturnya pembangunan yang mengganggu penataan wilayah dan kawsan kota.

Faktor yang Mempengaruhi Keberhasilan Kebijakan Izin Mendirikan Bangunan (IMB) Dalam Meningkatkan Pendapatan Asli Daerah (PAD).

Mencermati perkembangan pembangunan di Kabupaten Pangkep sebagai instansi yang melakukan penerapan implementasi kebijakan maka perlu dilaksanakan dengan seefektif mungkin. Hal ini sangat bermanfaat karena menjadi sasaran yang dapat mendukung implementasi kebijakan untuk mendorong bebrapa kegiatan pembangunan fisik agar lebih teratur dan terarah. Selain itu efektifitas pengimplementasian IMB diharapkan dapat meeningkatkan Pendapatan Asli Daerah (PAD) dari kabupaten pangkep yang bersumber dari retribusi IMB.

Tuntutan untuk mengefektifkan kebijakan IMB dalam rangka mengelola potensi sumber daya daerah, agar dapat memberikan manfaat bagi peembangunan daerah Kabupaten Pangkep. Upaya tersebut didukung dari meningkatnya bangunan fisik, sehingga apabila dikelola dengan benar dapat menjadi potensi yang baik untuk meningkatkan PAD yang bersumber dari retribusi IMB.

Kabupaten Pangkep memiliki potensi pendapatan yang cukup besar dari penerimaan retribusi IMB dengan pengolahan secara maksimal. Kabupaten Pangkep menjadi daerah dengan pendapatan yang cukup optimal. Pesatnya pembangunan di Kabupaten Pangkep harus mendapatkan pengawasan dengan efektif. Retribusi IMB merupakan sumber yang sangat besar terhadap penerimaan daerah.

Tujuan dari kepemilikan IMB yaitu sebagai pegangan masyarakat yang berdasarkan hokum berlaku agar masyarakat menjadi lebih nyaman dana man pada saat melakukan pembangunan. Dengan terbitnya IMB maka pembangunan telah memenuhi unsur persyaratan kelayakan administrasi, teknis dan ekologis untuk melakukan pembangunan. Sebagai konsekuensi dalam memberikan pelayanan penerbitan IMB oleh daerah, maka masyarakat berkewajiban untuk membayarkan retribusi. Penerbitan IMB akan memberikan pemassukan terhadap pendapatan asli daerah (PAD) yang bersumber dari retribusi IMB itu sendiri.

Untuk mencapai sasaran keberhasilan implementasi kebijakan, maka dilakukan penyusunan rencana untuk menetapkan jumlah pendapatan dari retribusi IMB sebagai hasil pendapatan daerah setiap tahunnya. Langkah ini dilakukan untuk memperkirakan pencapaian penerimaan retribusi IMB setiap tahunnya. Berdasarkan objek retribusi yang ada seperti rumah tinggal, bangunan usaha maupun bangunan pemerintah sehingga pencapaian penerimaan daerah ari retribusi IMB dapat diperkirakan.

Sejak diteetapkan Peraturan daerah Nomor 8 Tahun 2011 tentang retribusi IMB, dan mulai efektif diberlakukan, pelaksanaan kebijakan IMB mulai sedikit efektif terhadap penerimaan pendapatan asli daerah (PAD). Berdasarkan penetapan peraturan daerah tersebut maka retribusi IMB merupakan salah satu sumber pendapatan daerah. Namun saat ini penerimaan retribusi IMB belum mencapai target sasaran yang telah ditentukan setiap tahunnya.

\section{KESIMPULAN DAN SARAN}

Berdasarkan hasil analisis dapat disimpulkan bahwa penerapan implementasi kebijakan belum berjalan secara efektif, salah satu factor yaitu sumber daya yang masih kurang. Dari adanya kendala tersebut dapat pula mempengaruh pemerintah daerah Kabupaten Pangkep. Factor kedua yaitu pentingnya sumber daya yang kompeten agar dapat melakukan pengawasan dan pengendalian terhadap pembangunan yang dilakukan masyarakat. Serta perlunya kerja sama dengan beberapa instansi terkait. Perlunya dilakukan peningkatan terhadap kompetensi staf melalui beberapa pelatihan, workshop, seminar dan pendidikan. perlu dilakukan control pada pembangunan fisik pada petugas agar bangunan tersebut dapat diawasi secara langsung, perlu melakukan dengan 
ketat terhadap pembangunan fisik yang dilakukan oleh masyarakat, agar masyarakat patuh terhadap.

\section{DAFTAR PUSTAKA}

Abdul Wahab, S., 2008. Analisis Kebijaksanaan : Dari Formulasi ke Kebijaksanaan Negara, Bumi Aksara, Jakarta

Arikunto, S., 2010. Prosedur Penelitian, Rineka Cipta, Jakarta.

Baleke, 2016. [Tesis] Implementasi Kebijakan Pelayanan IMB di Nunukan.

Budi Winarno, 2012. Implementasi Kebijakan Publik dan Aplikasinya. Mizan, Bandung.

Carunia Mulya Firdauzy, 2017. Kebijakan dan Strategi Peningkatan Pendapatan Asli Daerah Dalam Pembangunan Nasional. Yayasan Pustaka Obor. Jakarta.

Cyntia Mellisa Takumangsang, 2013. Implementasi Kebijakan IMB dibadan Pelayanan Perizinan Terpadu Kota Menado.

Dwiyanto, Agus. 2012. Reformasi Birokrasi Publik di Indonesia. Yogyakarta, Pusat Media.

Dwiyanto, Agus. 2008. Mewujudkan Good Governance Melalui Pelayanan Publik. Yogyakarta,Gadjah

Halim, Kusufi, 2016. Akuntansi Keuangan Daerah. Salemba Empat, Jakarta.

Halim, 2007. Manajemen Keuangan Daerah, Salemba Empat, Jakarta.

Irsa Yonanda. 2017. [Jurnal] Efektivitas Pelayanan IMB pada Sektor Pariwisata di Kota Batu Malang.

Ismail, MH.HM dkk, 2010. Menuju Pelayanan Prima. Malang: Program Sekolah Demokrasi.

Leo Agustino, 2008. DasarDasar Kebijakan Publik. Alfabet. Jakarta.

Keban, Y. T., 2008. Enam Dimensi Strategis Administrasi Publik : Konsep Teori dan Isu, Gava Media, Yogyakarta.

Kurniawan, Agung, 2005, Transformasi Pelayanan Publik, PT. Pembaharuan, Yogyakarta.

Kusuma, 2012. Kualitas Izin Mendirikan Bangunan. Jakarta

Mardiasmo, 2012. Perpajakan. CV. Andi Ofset. Yogyakarta.

Moleong, 2006. Metode Penelitian Kualitatif, Remaja Rosdakarya, Bandung. 